\title{
Phonon Frequency Spectrum and Lattice Dynamics and Normal Coordinate Analysis of $\mathrm{HTSC} \mathrm{Tl}_{2} \mathrm{Ca}_{2} \mathrm{Ba}_{2} \mathrm{Cu}_{3} \mathrm{O}_{10}$
}

\author{
K.Sonamuthu \\ J.N.R.Mahavidyalaya Port Blair, Andaman
}

\begin{abstract}
The lattice dynamics of the high temperature superconductors $\mathrm{Tl}_{2} \mathrm{Ca}_{2} \mathrm{Ba}_{2} \mathrm{Cu}_{3} \mathrm{O}_{10}$ has been investigated on the basis of the three body force shell model (TSM). The various interactions between ions are treated on a general way without making them numerically equal. The phonon frequency at the zone centre of Brillouin zone are presented and the vibrational assignments are discussed. Further the normal coordinate calculation has also been employed to study the vibrational analysis of this compound. The normal coordinate analysis of the superconductor $\mathrm{Tl}_{2} \mathrm{CaBa}_{2} \mathrm{Cu}_{2} \mathrm{O}_{8}$ has been calculated by using Wilson's F-G matrix method which is useful for the confirmation of our present investigation. The vibrational frequencies and the potential energy distribution (PED) of the optically active phonon modes are also presented.
\end{abstract}

DOI: $10.7176 / \mathrm{APTA} / 80-04$

Publication date:October $31^{\text {st }} 2019$

\section{Introduction}

The study of the lattice dynamics of the high-temperature superconductors is of importance not only for the overall physical characterization of these compounds but also for an assessment of the role played by the phonons i.e., the superconducting phenomenon. A lattice dynamical study requires the knowledge of the crystal structure and the particle interactions. Usually the crystal structure is determined using X-ray diffraction. For particle interactions one has to use models, which represent the characteristic of the electronic structure and its effect on ionic interaction in a relevant manner. In lattice dynamics the ionic interactions are expressed interms of force constants.

Cox et.al[1] have refined the structure of high-temperature superconductors $\mathrm{Tl}_{2} \mathrm{Ca}_{2} \mathrm{Ba}_{2} \mathrm{Cu}_{3} \mathrm{O}_{10}$ using neutron and powder diffraction data. Raman and infrared active modes of $\mathrm{Tl}_{2} \mathrm{Ca}_{2} \mathrm{Ba}_{2} \mathrm{Cu}_{3} \mathrm{O}_{10}$ have been calculated by Kulkarni et.al[2] in the frame work of shell models. Belosiudov et.al[3] have calculated vibrational spectrum of $\mathrm{Tl}_{2} \mathrm{Ca}_{2} \mathrm{Ba}_{2} \mathrm{Cu}_{3} \mathrm{O}_{10}$ using interatomic interactions. A high resolution neutron diffraction study on $\mathrm{Tl}_{2} \mathrm{Ca}_{2} \mathrm{Ba}_{2} \mathrm{Cu}_{3} \mathrm{O}_{10}$ is contributed by Ogborne et.al[4].

In the present work we start with a more general approach in the framework of the three body-force shell model (TSM) with R \# S \# T to calculate the lattice dynamics frequencies. The values of the phonon frequencies calculated in this present work at zone center by the three body force shell model is in good agreement with the available Raman and infrared values. Further a normal coordinate analysis has also been attempted for the superconductor $\mathrm{Tl}_{2} \mathrm{Ca}_{2} \mathrm{Ba}_{2} \mathrm{Cu}_{3} \mathrm{O}_{10}$ using Wilson's F-G matrix method for the confirmation of our present investigations. The vibrational frequencies and the potential energy distribution (PED) of the optically active modes are also reported.

\section{Theoretical Consideration}

\subsection{Lattice dynamics of $\mathrm{Tl}_{2} \mathrm{Ca}_{2} \mathrm{Ba}_{2} \mathrm{Cu}_{3} \mathrm{O}_{10}$ based on the shell model}

The calculation of lattice dynamical vibration frequencies of $\mathrm{Tl}_{2} \mathrm{Ca}_{2} \mathrm{Ba}_{2} \mathrm{Cu}_{3} \mathrm{O}_{10}$ system is performed by three-body force shell model (TSM) calculations. In the shell model calculation the equations of the motion for the code coordinate $\mathbf{U}$ and the shell coordinate $\mathbf{W}$ are expressed as follows:

$$
\begin{gathered}
-M \varpi^{2} U=\left(R+Z C^{\prime} Z\right) \boldsymbol{U}+\left(T+Z C^{\prime} Y\right) \boldsymbol{W} \\
0=\left(T^{\prime}-Y C^{\prime} Z\right) \boldsymbol{U}\left(S+K+Y C^{\prime} Y\right) \boldsymbol{W}
\end{gathered}
$$

With $Z C^{\prime} Z=Z[Z+2 f(a)] C+V$ where $\mathrm{M}, \mathrm{Z}$ and $\mathrm{Y}$ are diagonal matrices representing the mass ionic charge on the shell. $R, S$ and $T$ are matrices specifying short-range core-core, shell-shell and core-shell interactions, respectively. $\mathrm{V}$ is the matrix describing the three-body overlap interactions and $\mathrm{f}(\mathrm{a})$ is related to overlap integrals of electron wave function. $\mathbf{U}$ and $\mathbf{W}$ are the vectors describing the ionic displacements and deformations respectively.

In the earlier approaches the $R, S$ and $T$ elements were considered to be equal to one another. In the present investigation, we have started with an approach such that $R \# S \# T$ [5]. That is the various interactions between the ions are treated in a more general way without making them numerically equal. The dynamical matrix of the model consists of long-range Coulomb and three-body interactions and the short-range overlap repulsions. The off-diagonal elements of this matrix along the symmetry directions chain a completely new term having a significant contribution for unequal $R, S$ and $T$.

The lattice dynamical calculation of high-temperature superconductors is explained using an interionic potential consisting of long-range Coulomb part and a short-range Potential of Born-Mayer form [6] 


$$
V_{i j}=a_{i j} \exp \left(-b_{i j} r\right)
$$

Where $i, j$ label the ions and $r$ is their separation. The parameters $a_{i j}$ and $b_{i j}$ are the pair potentials and the parameters $\mathrm{Y}$ and $\mathrm{K}$ determine the electronic polarizabilities. The parameters used in the present calculations are given in Table 1. Phonon frequencies are calculated using the force constants derived from the interionic potential. Following Leaner et a1 [7] interionic pair potentials for short-rang interactions can be transferred from one structure to another in similar environments. The force constants evaluated by this method are in good agreement with the evaluated values [8]

\subsection{Normal coordinate analysis of the zero wave vector vibrations of $\mathrm{Tl}_{2} \mathrm{Ca}_{2} \mathrm{Ba}_{2} \mathrm{Cu}_{3} \mathrm{O}_{10}$}

The study of lattice vibrations and the free carriers is important for the understanding of the physical nature of high temperature superconductors. Raman and far-infrared studies of these superconductors have contributed significantly to the understanding of new class of superconductors. Cardona and coworkers [9] studied the infrared and Raman spectra of the super conducting cuparate perovskites $\mathrm{MBaCu}_{2} \mathrm{O}_{2}(\mathrm{M}=\mathrm{Nd}, \mathrm{Er}, \mathrm{Dy}$, Tm and $\mathrm{Eu})$ and reproted the possible origins of phonon softening and the systematic variation of phonon frequencies with the ionic radius. Here an attempt has been made to perform the normal coordinate analysis for the phonon frequencies and the form of the zero wave vector vibrations for the $\mathrm{Tl}_{2} \mathrm{Ca}_{2} \mathrm{Ba}_{2} \mathrm{Cu}_{3} \mathrm{O}_{10}$ superconductors.

The high Tc superconductor $\mathrm{Tl}_{2} \mathrm{Ca}_{2} \mathrm{Ba}_{2} \mathrm{Cu}_{3} \mathrm{O}_{10}$ System crystallizes in the body-centered tetragonal (bct) system which belongs to the space group $14 / \mathrm{mmm}\left(\mathrm{D}^{17} 4 \mathrm{~h}\right)$ The body-centered tetragonal (bct) unit cell of $\mathrm{Tl}_{2} \mathrm{Ca}_{2} \mathrm{Ba}_{2} \mathrm{Cu}_{3} \mathrm{O}_{10}$ and the numbering of the atoms are shown in Fig. 1. The 19 atoms of the unit cell yield a total of 38 optical vibrational modes. All of above calculations are made at $q=0$. One of $A_{2 u}$ and $E_{u}$ modes corresponds to acoustic vibrations with frequency

$$
\begin{aligned}
& \varpi=0 \text {. These normal modes are distributed as follows. } \\
& \mathrm{A}_{1 \mathrm{~g}}+\mathrm{E}_{\mathrm{g}}+\mathrm{A}_{2 \mathrm{u}}+\mathrm{E}_{\mathrm{u}} \rightarrow \text { from the motion of } 2 \mathrm{Tl} \text { atoms } \\
& \mathrm{A}_{\mathrm{lg}}+\mathrm{E}_{\mathrm{g}}+\mathrm{E}_{\mathrm{u}} \quad \rightarrow \text { from the motion of 2Ba atoms } \\
& \mathrm{A}_{1 \mathrm{~g}}+\mathrm{E}_{\mathrm{g}}+\mathrm{A}_{2 \mathrm{u}} \quad+\mathrm{E}_{\mathrm{u}} \rightarrow \text { from the motion of } 2 \mathrm{Ca} \text { atoms } \\
& \mathrm{A}_{1 \mathrm{~g}}+\mathrm{E}_{\mathrm{g}}+\mathrm{A}_{2 \mathrm{u}} \quad+\mathrm{E}_{\mathrm{u}} \rightarrow \text { from the motion of } 2 \mathrm{Cu}(1) \text { atoms } \\
& \mathrm{A}_{2 \mathrm{u}}+\mathrm{E}_{\mathrm{u}} \rightarrow \text { from the motion of } \mathrm{Cu}(2) \text { atoms } \\
& \mathrm{A}_{1 \mathrm{~g}}+2 \mathrm{E}_{\mathrm{g}}+\mathrm{B}_{1 \mathrm{~g}}+2 \mathrm{~A}_{2 \mathrm{u}}+2 \mathrm{~B}_{2 \mathrm{u}}+3 \mathrm{E}_{\mathrm{u}} \\
& \text { from the motion of } \mathrm{O}(1) \text { atoms along c-axis. }
\end{aligned}
$$

$\mathrm{A}_{1 \mathrm{~g}}+\mathrm{E}_{1 \mathrm{~g}}+2 \mathrm{~A}_{2 \mathrm{u}}+2 \mathrm{E}_{\mathrm{u}} \rightarrow$ from the motion of $\mathrm{O}(2)$ atoms along the $\mathrm{b}$-axis.

$\mathrm{A}_{1 \mathrm{~g}}+\mathrm{E}_{\mathrm{g}}+\mathrm{A}_{2 \mathrm{u}}+\mathrm{E}_{\mathrm{u}} \rightarrow$ from the motion of $\mathrm{O}(3)$ atoms along the a-axis.

Subtracting the translation modes $\mathrm{A} 2 \mathrm{u}+\mathrm{B}_{2 \mathrm{u}}+\mathrm{E}_{\mathrm{u}}$ the $\mathrm{q}=0$ optical modes involved in an irreducible representation are as follows.

$$
\Gamma_{\text {opt }}=7 \mathrm{~A}_{1 \mathrm{~g}}+\mathrm{B}_{1 \mathrm{~g}}+8 \mathrm{E}_{\mathrm{g}}+9 \mathrm{~A}_{2 \mathrm{u}}+2 \mathrm{~B}_{2 \mathrm{u}}+11 \mathrm{E}_{\mathrm{u}}
$$

The species belonging to $A_{1 g}, B_{1 g}$ and $E_{g}$ are Raman active modes whereas $A_{2 u}$ and $B_{u}$ are infrared active modes. The $\mathrm{A}_{2 \mathrm{u}}$ and $\mathrm{A}_{1 \mathrm{~g}}$ modes involves displacement along crystallographic c-axis, the $\mathrm{B}_{2 \mathrm{u}}$ and $\mathrm{E}_{\mathrm{g}}$ modes along the $b$-axis and the $\mathrm{B}_{1 \mathrm{~g}}$ and $\mathrm{E}_{\mathrm{u}}$ modes along the a-axis. The normal coordinate calculation was performed using the programs GMAT and FPERT given by Fuhrer et al [10]. The general agreement between the evaluated and observed normal frequencies of $\mathrm{Tl}_{2} \mathrm{Ca}_{2} \mathrm{Ba}_{2} \mathrm{Cu}_{3} \mathrm{O}_{10}$ is good. The calculated force constants using the above programs are given in Table 2. It is interesting to note that the evaluated frequencies given in Table 3 agree favourably with the experimental values.

To check whether the chosen set of vibrational frequencies makes the maximum contribution to the potential energy associated with the normal coordinate frequencies of the superconducting material, the potential energy distribution was calculated using the equation.

$$
P E D=\left(\begin{array}{lll}
F_{i j} & L^{2}{ }_{i k}
\end{array}\right) / \lambda_{k}
$$

Where PED is the combination of the i-th symmetry coordinate to the potential energy of the vibration whose frequency is $v_{k}, F_{i j}$ are potential constants, $L_{i k}$, are $\mathrm{L}$ matrix elements and $\lambda_{k}=4 \pi^{2} C^{2} v_{k}^{2}$.

\section{Results and Discussion: $\left(\mathrm{Tl}_{2} \mathrm{Ca}_{2} \mathrm{bBa}_{2} \mathrm{Ca}_{3} \mathrm{O}_{10}\right)$ 3.1 Lattice Dynamical Calculations using Shell model.}

The Lattice Dynamical Calculations based on modified TSM reproduce the observed frequencies of Raman and infrared active modes reasonable which are given in table 3. The calculated frequencies are in good agreement with the available experimental values. The lowest calculated active $A_{1 g}$ mode frequency at $104 \mathrm{~cm}^{-1}$ is due to the vibration of $\mathrm{Ba}, \mathrm{Cu}(1)$ and $\mathrm{Cu}(2)$ atoms and this agrees very well with the observed frequency at $99 \mathrm{~cm}^{-1}$. The evaluated Raman phonon frequency at $126 \mathrm{~cm}^{-1}$ is due to the vibration of $\mathrm{Tl}, \mathrm{Ba}$ and $\mathrm{Cu}(1)$ atoms and the observed frequency at $133 \mathrm{~cm}^{-1}$ agrees very well with the calculated frequency. Here the $\mathrm{Tl}$ atom is vibrating $180^{\circ}$ out of phase to $\mathrm{Ba}$ and $\mathrm{Cu}(1)$ atoms. Similarly thee calculated Raman phonon frequency at $144 \mathrm{~cm}^{-1}$ is due to the vibration of $\mathrm{Cu}(1), \mathrm{Ba}$ and $\mathrm{Cu}(2)$ atoms and $\mathrm{Ba}$ atom is vibrating $180^{\circ}$ out of phase of $\mathrm{Cu}(1)$ and $\mathrm{Cu}(2)$ atoms and the observed frequency at $159 \mathrm{~cm}^{-1}$ agrees very well with the calculated frequency. The next calculated Raman 
phonon frequency at $290 \mathrm{~cm}^{-1}$ is due to the vibration of $\mathrm{O}(1), \mathrm{O}(4)$ and $\mathrm{Ca}$ atoms and its observed frequency is 270 $\mathrm{cm}^{-1}$. The evaluated Raman phonon frequency at $401 \mathrm{~cm}^{-1}$ is due to the vibration of $\mathrm{O}(1), \mathrm{O}(4)$ and $\mathrm{Ca}$ atoms and the $\mathrm{Ca}$ atom is vibrating $180^{\circ}$ out of phase to $\mathrm{O}(1)$ and $\mathrm{O}(4)$ atoms and the observed frequency $407 \mathrm{~cm}^{-1}$ agrees very well with the calculated frequency. The evaluated phonon frequency $489 \mathrm{~cm}^{-1}$ is due to Vibration of $\mathrm{O}(2)$ atoms. The maximum evaluated Raman frequency $608 \mathrm{~cm}^{-1}$ is due to the vibration of $\mathrm{O}(3)$ atoms and the observed frequency $601 \mathrm{~cm}^{-1}$ agrees very well with the calculated frequency. The evaluated Raman phonon frequency 256 $\mathrm{cm}^{-1}$ in $\mathrm{B}_{1 \mathrm{~g}}$ Symmetry is due to the vibration of $\mathrm{O}(1)$ and $\mathrm{O}(4)$ atoms and the observed frequency $245 \mathrm{~cm}^{-1}$ agrees very well with calculated frequency.

Similarly, the evaluated Raman phonon frequency at $66 \mathrm{~cm}^{-1}$ in $\mathrm{Eg}$ symmetry is due to the vibration of Ba, $\mathrm{Cu}$ (1) atoms and are in plane with $\mathrm{Ca}$ atom. The Raman phonon frequency at $136 \mathrm{~cm}^{-1}$ is due to the vibration of $\mathrm{Tl}$ atom. The evaluated Raman frequency at $140 \mathrm{~cm}^{-1}$ is due to $\mathrm{Cu}(1), \mathrm{Ba}$ and $\mathrm{Ca}$ atoms and $\mathrm{Ba}$ atom is vibrating $180^{\circ}$ out of phase of $\mathrm{Cu}(1)$ and $\mathrm{Ca}$ atoms. The evaluated phonon frequency at $259 \mathrm{~cm}^{-1}$ is due to the bending vibration of $\mathrm{O}(1), \mathrm{O}(4)$ and $\mathrm{Ca}$ atoms. The phonon frequency at $375 \mathrm{~cm}^{-1}$ due to stretching vibration of $\mathrm{O}(1)$ and $\mathrm{O}(4)$ atoms. The calculated phonon frequency $450 \mathrm{~cm}^{-1}$ is due to the vibration of $\mathrm{O}(2)$ atoms. The phonon frequency $489 \mathrm{~cm}^{-1}$ is due to the vibration of $\mathrm{O}(3)$ atom. The highest calculated phonon frequency at $555 \mathrm{~cm}^{-1}$ in Eg symmetry is due to the stretching vibration of $\mathrm{O}(1)$ atoms.

The lowest calculated infrared phonon frequency in $\mathrm{A}_{2 \mathrm{u}}$ symmetry at $72 \mathrm{~cm}^{-1}$ is due to the vibrations of $\mathrm{C}_{\mathrm{u}}(1)$ and $\mathrm{C}_{\mathrm{u}}(2)$ atoms and the observed frequency at $128 \mathrm{~cm}^{-1}$ agrees very well with the calculated frequency. The evaluated infrared phonon frequency at $103 \mathrm{~cm}^{-1}$ is due to the vibration of $\mathrm{Cu}(2), \mathrm{Cu}(1)$ and $\mathrm{Tl}$ atoms in which $\mathrm{Tl}$ atom vibrates $180^{\circ}$ out of phase to $\mathrm{Cu}(2)$ and $\mathrm{Cu}(1)$ atoms and the observed frequency $131 \mathrm{~cm}^{-1}$ agrees very well with the calculated frequency. The next evaluated infrared phonon frequency at $150 \mathrm{~cm}^{-1}$ is due to the vibration of $\mathrm{Cu}(2)$ and $\mathrm{Cu}(1)$ atoms and the observed frequency at $151 \mathrm{~cm}^{-1}$ agrees very well with the calculated frequency.

The evaluated infrared phonon frequency at $190 \mathrm{~cm}^{-1}$ is due to the vibration of $\mathrm{O}(4), \mathrm{O}(1)$ and $\mathrm{Ca}$ atoms and its observed frequency $197 \mathrm{~cm}^{-1}$ agrees very well with the calculated phonon frequency. The next evaluated infrared phonon frequency at $365 \mathrm{~cm}^{-1}$ is due to the vibration of $\mathrm{O}(2), \mathrm{Ca}$ and $\mathrm{O}(1)$ atoms. Here $\mathrm{Ca}$ atom is vibrating $180^{\circ}$ out of phase to $\mathrm{O}(2)$ and $\mathrm{O}(1)$ atoms and the observed frequency at $372 \mathrm{~cm}^{-1}$ agrees very well with the calculated frequency. The calculated frequency at $420 \mathrm{~cm}^{-1}$ is due the vibration of $\mathrm{O}(4), \mathrm{O}(2)$ and $\mathrm{Ca}$ atoms in which Ca atom vibrates $180^{\circ}$ out of phase to $\mathrm{O}(4)$ and $\mathrm{O}(2)$ atoms and the observed frequency $421 \mathrm{~cm}^{-1}$ agrees very well with the calculated frequency. The next higher calculated infrared phonon frequency at $444 \mathrm{~cm}^{-1}$ is due to the vibration of $\mathrm{O}(2), \mathrm{O}(1)$ and $\mathrm{Ca}$ atoms and the observed frequency at $454 \mathrm{~cm}^{-1}$ agrees very well with the calculated frequency. The highest calculated infrared phonon frequency in $\mathrm{A}_{2 \mathrm{u}}$ symmetry at $607 \mathrm{~cm}^{-1}$ is due to the vibration of $\mathrm{O}(3)$ atom and its observed frequency at $616 \mathrm{~cm}^{-1}$ agrees very well with the calculated frequency.

The evaluated phonon infrared frequency in $\mathrm{B}_{2 \mathrm{u}}$ symmetry at $133 \mathrm{~cm}^{-1}$ is due to the vibration of $\mathrm{O}(4)$ and $\mathrm{O}(1)$ atoms. The calculated frequency at $306 \mathrm{~cm}^{-1}$ is due to the vibration of $\mathrm{O}(4)$ and $\mathrm{O}(1)$ atoms.

The lowest calculated infrared phonon frequency in Eu symmetry is $70 \mathrm{~cm}^{-1}$ which is due to the vibration of $\mathrm{Cu}(2)$ and $\mathrm{Tl}$ atoms and the $\mathrm{Tl}$ atom is vibrating out of plane to $\mathrm{Cu}(2)$ atom and the observed frequency $70 \mathrm{~cm}^{-1}$ agrees very well with the calculated frequency. The calculated infrared frequency $101 \mathrm{~cm}^{-1}$ is due to the vibration of $\mathrm{Tl}$ and $\mathrm{Cu}(2)$ atoms and the observed frequency at $101 \mathrm{~cm}^{-1}$ agrees very well with the calculated phonon frequency. The evaluated infrared phonon frequency at $145 \mathrm{~cm}^{-1}$ is due to the vibration of $\mathrm{Cu}(1), \mathrm{Cu}(2)$ and $\mathrm{Ba}$ atoms in which $\mathrm{Ba}$ atom is vibrating $180^{\circ}$ out of phase to $\mathrm{Cu}(1)$ and $\mathrm{Cu}(2)$ atoms and the observed frequency at $145 \mathrm{~cm}^{-1}$ agrees very well with the calculated frequency. The calculated infrared frequency at $255 \mathrm{~cm}^{-1}$ is due to vibration of $\mathrm{Cu} \mathrm{O}(4)$ and $\mathrm{O}(1)$ atoms which performs bending bond vibrations and the observed frequency at $255 \mathrm{~cm}^{-1}$ agrees very well with the calculated frequency. The next calculated infrared frequency at $359 \mathrm{~cm}^{-1}$ is due to the vibration of $\mathrm{O}(4)$ and $\mathrm{O}(1)$ atoms and the observed frequency at $359 \mathrm{~cm}^{-1}$ agrees very well with the calculated frequency. The calculated infrared phonon frequency at $387 \mathrm{~cm}^{-1}$ is due to the vibration of $\mathrm{O}(2)$ and $\mathrm{O}(3)$ atoms and the observed frequency at $397 \mathrm{~cm}^{-1}$ agrees very well with the calculated frequency.

The calculated infrared phonon frequency at $435 \mathrm{~cm}^{-1}$ is due to the vibration of $\mathrm{Ca}, \mathrm{O}(1)$ and $\mathrm{O}(4)$ atoms. Here $\mathrm{Ca}$ atom vibrates $180^{\circ}$ out of phase to $\mathrm{O}(1)$ and $\mathrm{O}(4)$ atoms and the observed frequency at $446 \mathrm{~cm}^{-1}$ agrees very well with the calculated frequency. The evaluated frequency at $451 \mathrm{~cm}^{-1}$ is due to the vibration of $\mathrm{O}(3)$ and $\mathrm{O}(2)$ atoms and the $\mathrm{O}(2)$ atom vibraties out of plane to $\mathrm{O}(3)$ atom and the observed frequency at $456 \mathrm{~cm}^{-1}$ agrees very well with the calculated frequency. The evaluated infrared frequency at $555 \mathrm{~cm}^{-1}$ is due to the vibration of $\mathrm{O}(1)$ atom which performs stretching vibrations and the observed frequency at $556 \mathrm{~cm}^{-1}$ agrees very well with the calculated frequency. The highest calculated infrared frequency in Eu symmetry at $569 \mathrm{~cm}^{-1}$ is due to the vibration of $\mathrm{O}(4)$ atom performs stretching vibration and the observed frequency $563 \mathrm{~cm}^{-1}$ agrees very well with the calculated frequency.

\subsection{Normal coordinate analysis}

The Normal Coordinate Analysis of $\mathbf{T l}_{2} \mathrm{Ca}_{2} \mathrm{Ba}_{2} \mathrm{Cu}_{3} \mathrm{O}_{10}$ reproduces the observed frequencies of Raman and infrared 
active modes reasonable which are given in table 3 . The calculated frequencies are in good agreement with the available experimental values. The lowest calculated active $A_{1 \mathrm{~g}}$ mode frequency at $110 \mathrm{~cm}^{-1}$ is due to the vibration of $\mathrm{Ba}, \mathrm{Cu}(1)$ and $\mathrm{Cu}(2)$ atoms. The evaluated Raman phonon frequency at $130 \mathrm{~cm}^{-1}$ is due to the vibration of $\mathrm{Tl}$, $\mathrm{Ba}$ and $\mathrm{Cu}(1)$ atoms. Here the $\mathrm{Tl}$ atom is vibrating $180^{\circ}$ out of phase to $\mathrm{Ba}$ and $\mathrm{Cu}(1)$ atoms. Similarly thee calculated Raman phonon frequency at $151 \mathrm{~cm}^{-1}$ is due to the vibration of $\mathrm{Cu}(1), \mathrm{Ba}$ and $\mathrm{Cu}(2)$ atoms and $\mathrm{Ba}$ atom is vibrating $180^{\circ}$ out of phase of $\mathrm{Cu}(1)$ and $\mathrm{Cu}(2)$ atoms. The next calculated Raman phonon frequency at 281 $\mathrm{cm}^{-1}$ is due to the vibration of $\mathrm{O}(1), \mathrm{O}(4)$ and Ca atoms. The evaluated Raman phonon frequency at $412 \mathrm{~cm}^{-1}$ is due to the vibration of $\mathrm{O}(1), \mathrm{O}(4)$ and $\mathrm{Ca}$ atoms and the $\mathrm{Ca}$ atom is vibrating $180^{\circ}$ out of phase to $\mathrm{O}(1)$ and $\mathrm{O}(4)$ atoms. The evaluated phonon frequency $486 \mathrm{~cm}^{-1}$ is due to Vibration of $\mathrm{O}(2)$ atoms. The maximum evaluated Raman frequency $605 \mathrm{~cm}-1$ is due to the vibration of $\mathrm{O}(3)$ atoms. The evaluated Raman phonon frequency 261 $\mathrm{cm}-1$ in B1g Symmetry is due to the vibration of $\mathrm{O}(1)$ and $\mathrm{O}(4)$ atoms.

Similarly, the evaluated Raman phonon frequency at $70 \mathrm{~cm}-1$ in Eg symmetry is due to the vibration of Ba, $\mathrm{Cu}(1)$ atoms and are in plane with $\mathrm{Ca}$ atom. The Raman phonon frequency at $142 \mathrm{~cm}-1$ is due to the vibration of $\mathrm{Tl}$ atom. The evaluated Raman frequency at $164 \mathrm{~cm}-1$ is due to $\mathrm{Cu}(1), \mathrm{Ba}$ and $\mathrm{Ca}$ atoms and $\mathrm{Ba}$ atom is vibrating $180^{\circ}$ out of phase of $\mathrm{Cu}(1)$ and $\mathrm{Ca}$ atoms. The evaluated phonon frequency at $270 \mathrm{~cm}-1$ is due to the bending vibration of $\mathrm{O}(1), \mathrm{O}(4)$ and $\mathrm{Ca}$ atoms. The phonon frequency at $365 \mathrm{~cm}-1$ due to stretching vibration of $\mathrm{O}(1)$ and $\mathrm{O}(4)$ atoms. The calculated phonon frequency $411 \mathrm{~cm}-1$ is due to the vibration of $\mathrm{O}(2)$ atoms. The phonon frequency $471 \mathrm{~cm}-1$ is due to the vibration of $\mathrm{O}(3)$ atom. The highest calculated phonon frequency at $554 \mathrm{~cm}-1$ in Eg symmetry is due to the stretching vibration of $\mathrm{O}(1)$ atoms.

The lowest calculated infrared phonon frequency in A2u symmetry at $81 \mathrm{~cm}-1$ is due to the vibrations of $\mathrm{Cu}(1)$ and $\mathrm{Cu}(2)$ atoms. The evaluated infrared phonon frequency at $120 \mathrm{~cm}-1$ is due to the vibration of $\mathrm{Cu}(2)$, $\mathrm{Cu}(1)$ and $\mathrm{Tl}$ atoms in which $\mathrm{Tl}$ atom vibrates $180^{\circ}$ out of phase to $\mathrm{Cu}(2)$ and $\mathrm{Cu}(1)$ atoms. The next evaluated infrared phonon frequency at $148 \mathrm{~cm}-1$ is due to the vibration of $\mathrm{Cu}(2)$ and $\mathrm{Cu}(1)$ atoms. The evaluated infrared phonon frequency at $181 \mathrm{~cm}-1$ is due to the vibration of $\mathrm{O}(4), \mathrm{O}(1)$ and $\mathrm{Ca}$ atoms. The next evaluated infrared phonon frequency at $369 \mathrm{~cm}-1$ is due to the vibration of $\mathrm{O}(2), \mathrm{Ca}$ and $\mathrm{O}(1)$ atoms. Here $\mathrm{Ca}$ atom is vibrating $180^{\circ}$ out of phase to $\mathrm{O}(2)$ and $\mathrm{O}(1)$ atoms The calculated frequency at $411 \mathrm{~cm}-1$ is due the vibration of $\mathrm{O}(4), \mathrm{O}(2)$ and $\mathrm{Ca}$ atoms in which $\mathrm{Ca}$ atom vibrates $180^{\circ}$ out of phase to $\mathrm{O}(4)$ and $\mathrm{O}(2)$ atoms The next higher calculated infrared phonon frequency at $449 \mathrm{~cm}-1$ is due to the vibration of $\mathrm{O}(2), \mathrm{O}(1)$ and $\mathrm{Ca}$ atoms. The highest calculated infrared phonon frequency in A2u symmetry at $592 \mathrm{~cm}-1$ is due to the vibration of $\mathrm{O}(3)$ atom.

The evaluated phonon infrared frequency in B2u symmetry at $138 \mathrm{~cm}-1$ is due to the vibration of $\mathrm{O}(4)$ and $\mathrm{O}(1)$ atoms. The calculated frequency at $309 \mathrm{~cm}-1$ is due to the vibration of $\mathrm{O}(4)$ and $\mathrm{O}(1)$ atoms.

The lowest calculated infrared phonon frequency in Eu symmetry is $69 \mathrm{~cm}-1$ which is due to the vibration of $\mathrm{Cu}(2)$ and $\mathrm{Tl}$ atoms and the $\mathrm{Tl}$ atom is vibrating out of plane to $\mathrm{Cu}(2)$ atom. The calculated infrared frequency $105 \mathrm{~cm}-1$ is due to the vibration of $\mathrm{Tl}$ and $\mathrm{Cu}(2)$ atoms. The evaluated infrared phonon frequency at $152 \mathrm{~cm}-1$ is due to the vibration of $\mathrm{Cu}(1), \mathrm{Cu}(2)$ and $\mathrm{Ba}$ atoms in which $\mathrm{Ba}$ atom is vibrating $180^{\circ}$ out of phase to $\mathrm{Cu}(1)$ and $\mathrm{Cu}(2)$ atoms. The calculated infrared frequency at $228 \mathrm{~cm}-1$ is due to vibration of $\mathrm{Cu} \mathrm{O}(4)$ and $\mathrm{O}(1)$ atoms which performs bending bond vibrations. The next calculated infrared frequency at $358 \mathrm{~cm}-1$ is due to the vibration of $\mathrm{O}(4)$ and $\mathrm{O}(1)$ atoms. The calculated infrared phonon frequency at $390 \mathrm{~cm}-1$ is due to the vibration of $\mathrm{O}(2)$ and $\mathrm{O}(3)$ atoms.

The calculated infrared phonon frequency at $441 \mathrm{~cm}-1$ is due to the vibration of $\mathrm{Ca}, \mathrm{O}(1)$ and $\mathrm{O}(4)$ atoms. Here $\mathrm{Ca}$ atom vibrates $180^{\circ}$ out of phase to $\mathrm{O}(1)$ and $\mathrm{O}(4)$ atoms. The evaluated frequency at $458 \mathrm{~cm}-1$ is due to the vibration of $\mathrm{O}(3)$ and $\mathrm{O}(2)$ atoms and the $\mathrm{O}(2)$ atom vibraties out of plane to $\mathrm{O}(3)$ atom The evaluated infrared frequency at $562 \mathrm{~cm}-1$ is due to the vibration of $\mathrm{O}(1)$ atom which performs stretching vibrations. The highest calculated infrared frequency in Eu symmetry at $571 \mathrm{~cm}-1$ is due to the vibration of $\mathrm{O}(4)$ atom performs stretching vibration .

Vibrational modes on the region 400-500 cm-1 are attributed to $\mathrm{Ca}-\mathrm{O}(2)$ stretching. The present potential energy distribution confirms our conclusion. The lower frequency modes involve the small displacement of Ca$\mathrm{O}(2)$ and $\mathrm{Ba}-\mathrm{O}$ and the angular displacement of $\mathrm{O}-\mathrm{Ca}-\mathrm{O}$. The evaluated frequencies using the normal coordinate analysis method listed in table 3 agree favourably with the calculated lattice dynamical frequencies and observed experimental frequencies.

\section{Conclusion}

The theoretical phonon frequencies obtained by the lattice dynamics and the normal coordinate analysis method agrees very well will the available Raman and infrared frequencies. This calculation attributes not only the phonon frequency in center of the Brilioun zone but also supports the strong electron-phonon interaction in the hightemperature superconductor $\mathrm{Tl}_{2} \mathrm{Ca}_{2} \mathrm{Ba}_{2} \mathrm{Cu}_{3} \mathrm{O}_{10}$ 


\section{References}

[1] D.E., Cox, C.C. Tovaradi, M.A., Subramanian, J. Gopalkrishnan, and A.W. Sleight, Phys. Rev. B 38, 6624 (1988).

[2] A.D. Kulkarani, J.Prade, F.W. DE Watte, W. Kress, and U. Schroder, Phys. Rev. B 40, 2624 (1989).

[3] V.R. Belosludov, M.Y. LAVRentieV, and S.A. Syskin, Int. J.Mod. Phys. B 5, 3109 (1991)

[4] D.M. Ogborne, M.T. Weller, and P.C. Lanchester, Physica C 200, 207 (1992)

[5] S. MOHAN, S.DURAI, and G.VAIDYANATHAN, Indian J.Phys. 60A, 137 (1986)

[6] S. OnARI, T.Hiroaki, K.Onghime, H.Honme, and T. Arai, Solid State Commun. 3. 303 (1988)

[7] N. Lehner, H.RAuh, K.Strobel, R.Geick, G.Heger, J. Bouillot, B.RenKer, M.Rousseau, and W.J. Stirling, J. Phys. C 15, 6545 (1982).

[8] S.OnARI, A.OnO, T.Arai, and T.Mori, Physica B 165/166, 1235 (1990).

[9] C. Thomsen, M.Cardona, W.Kress, L.Genzel, M.BAuER, W.King, and A.Wittlin, Soild State Commun. 64, 727 (1987)

[10] H. Fuhrer, V.B. Kartha, K.G.KidD, P.J. Krueger, and H.H. Mantasch, Computer Programs for Infrared Spectrometry, Vol. V, Normal Coordinate Analysis National Research Council of Canada, Ottawa 1976

Table : 1

Parameters of the model: a, b are Born- Mayer constants: Z, Y, K, ionic charge, shell charge and on-site core-shell force constant of the ion, $v_{a}$ is the volume of the unit cell

\begin{tabular}{|c|c|c|c|}
\hline Interaction & & & b $\left(\AA^{-1}\right)$ \\
\hline T1-O (Same plane) & & & 2.80 \\
\hline T1-O (adj plane) & & & 3.55 \\
\hline $\mathrm{Ba}-\mathrm{O}$ & & & 2.90 \\
\hline $\mathrm{Ca}-\mathrm{O}$ & & & 3.10 \\
\hline $\mathrm{Cu}-\mathrm{O}$ & & & 3.35 \\
\hline $\mathrm{O}-\mathrm{O}$ & & & 3.00 \\
\hline ion & $\mathrm{Z}(|\mathrm{e}|)$ & $\mathrm{Y}(|\mathrm{e}|)$ & $\mathrm{k}\left(\mathrm{e}^{2} \mid \mathrm{v}_{\mathrm{a}}\right)$ \\
\hline $\mathrm{T} 1$ & 2.70 & 2.00 & 1000 \\
\hline $\mathrm{Ba}$ & 2.00 & 2.32 & 207 \\
\hline $\mathrm{Ca}$ & 2.02 & -0.50 & 1350 \\
\hline $\mathrm{Cu}$ & 2.00 & 3.22 & 1248 \\
\hline $\mathrm{O}(\mathrm{Cu}-\mathrm{O})$ plane & -1.90 & -2.70 & 310 \\
\hline $\mathrm{O}(\mathrm{T} 1-\mathrm{O})$ plane & -1.93 & -2.70 & 210 \\
\hline $\mathrm{O}(\mathrm{Ba}-\mathrm{O})$ plane & -1.93 & -2.70 & $310\left(\mathrm{~K}_{\|}\right)$ \\
\hline & & & $2100(\mathrm{~K} \perp)$ \\
\hline
\end{tabular}

Table : 2

Force constants for $\mathrm{Tl}_{2} \mathrm{Ca}_{2} \mathrm{Ba}_{2} \mathrm{Cu}_{3} \mathrm{O}_{10}$ (in units of $10^{2} \mathrm{Nm}^{-1}$ (stretching) and $10^{-18} \quad \mathrm{Nm}^{2}$ $\mathrm{rad}^{-2}$ (bending))

\begin{tabular}{llll}
\hline $\begin{array}{l}\text { Potential } \\
\text { Constants }\end{array}$ & bond type & distance $(\AA)$ & initial value \\
\hline $\mathrm{f}_{\mathrm{a}}$ & $\mathrm{Ca}-\mathrm{O}(1)$ & 2.467 & 1.06 \\
$\mathrm{f}_{\mathrm{b}}$ & $\mathrm{Ba}-\mathrm{O}(1)$ & 2.798 & 0.75 \\
$\mathrm{f}_{\mathrm{c}}$ & $\mathrm{Ba}-\mathrm{O}(2)$ & 2.819 & 1.10 \\
$\mathrm{f}_{\mathrm{d}}$ & $\mathrm{Ba}-\mathrm{O}(3)$ & 2.851 & 0.81 \\
$\mathrm{f}_{\mathrm{e}}$ & $\mathrm{Tl}-\mathrm{O}(1)$ & 2.003 & 0.30 \\
$\mathrm{f}_{\mathrm{g}}$ & $\mathrm{Tl}-\mathrm{O}(2)$ & 2.097 & 0.30 \\
$\mathrm{f}_{\mathrm{h}}$ & $\mathrm{Tl}-\mathrm{O}(3)$ & 3.108 & 0.61 \\
$\mathrm{f}_{\mathrm{k}}$ & $\mathrm{Tl}-\mathrm{O}(3)$ & 2.402 & 0.48 \\
$\mathrm{f}_{\mathrm{l}}$ & $\mathrm{Cu}-\mathrm{O}(1)$ & 1.932 & 0.145 \\
$\mathrm{f}_{\mathrm{m}}$ & $\mathrm{Cu}-\mathrm{O}(2)$ & 2.648 & 1.65 \\
$\mathrm{f}_{\mathrm{n}}$ & $\mathrm{Tl}-\mathrm{O}(3)-\mathrm{Tl}$ & -- & 0.31 \\
$\mathrm{f}_{\mathrm{p}}$ & $\mathrm{O}(1)-\mathrm{Cu}-\mathrm{O}(1)$ & -- & 0.25 \\
$\mathrm{f}_{\alpha}$ & $\mathrm{Tl}-\mathrm{O}(2)-\mathrm{Ba}$ & -- & 0.46 \\
$\mathrm{f}_{\beta}$ & $\mathrm{O}(2)-\mathrm{Tl}-\mathrm{O}(3)$ & -- & 0.80 \\
\hline
\end{tabular}


Table:3

Calculated Phonon frequencies of $\mathrm{Tl}_{2} \mathrm{Ca}_{2} \mathrm{Ba}_{2} \mathrm{Cu}_{3} \mathrm{O}_{10}$ (Values in the Parentheses are experimental frequencies).

\begin{tabular}{|c|c|c|c|}
\hline $\begin{array}{l}\text { Symmetery } \\
\text { species }\end{array}$ & $\begin{array}{l}\text { Frequency }\left(\mathrm{cm}^{-1}\right) \\
\text { Using Lattice } \\
\text { Dynamics }\end{array}$ & $\begin{array}{l}\text { Using Normal } \\
\text { Coordinate analysis }\end{array}$ & $\begin{array}{ll}\text { Potential } & \text { Energy } \\
\text { Distribution(\%) } & \end{array}$ \\
\hline \multirow[t]{7}{*}{$\mathrm{A}_{1 \mathrm{~g}}($ Raman $)$} & $104(99)$ & 110 & $\mathrm{f}_{\beta}(60) \mathrm{f}_{\mathrm{d}}(19) \mathrm{f}_{\mathrm{k}}(14)$ \\
\hline & $126(133)$ & 130 & $\mathrm{f}_{\mathrm{c}}(55) \mathrm{f}_{\mathrm{l}}(30)$ \\
\hline & $144(159)$ & 151 & $\mathrm{f}_{\mathrm{e}}(72) \mathrm{f}_{\mathrm{l}}(19)$ \\
\hline & $290(270)$ & 281 & $\mathrm{f}_{\mathrm{a}}(51) \mathrm{f}_{\alpha}(29)$ \\
\hline & 401(407) & 412 & $\mathrm{f}_{\mathrm{a}}(61) \mathrm{f}_{\mathrm{c}}(20) \mathrm{f}_{\mathrm{m}}(10)$ \\
\hline & $489(498)$ & 486 & $\mathrm{f}_{\mathrm{a}}(52) \mathrm{f}_{\mathrm{k}}(21) \mathrm{f}_{\mathrm{c}}(13)$ \\
\hline & $608(601)$ & 605 & $\mathrm{f}_{\mathrm{a}}(72) \mathrm{f}_{\alpha}(16)$ \\
\hline $\mathrm{B}_{1 \mathrm{~g}}$ & $256(245)$ & 261 & $\mathrm{f}_{\mathrm{a}}(56) \mathrm{f}_{\mathrm{k}}(14) \mathrm{f}_{\alpha}(10)$ \\
\hline \multirow[t]{8}{*}{$\mathrm{E}_{\mathrm{g}}$} & 66 & 70 & $\mathrm{f}_{\mathrm{c}}(60) \mathrm{f}_{\mathrm{e}}(14) \mathrm{f}_{\beta}(16)$ \\
\hline & 136 & 142 & $\mathrm{f}_{\mathrm{m}}(74) \mathrm{f}_{\mathrm{e}}(20)$ \\
\hline & 140 & 164 & $\mathrm{f}_{\mathrm{e}}(41) \mathrm{f}_{\mathrm{m}}(20) \mathrm{f}_{\mathrm{l}}(19)$ \\
\hline & 259 & 270 & $\mathrm{f}_{\mathrm{e}}(52) \mathrm{f}_{\mathrm{m}}(16) \mathrm{f}_{\mathrm{c}}(12)$ \\
\hline & 375 & 365 & $\mathrm{f}_{\mathrm{a}}(42) \mathrm{f}_{\mathrm{g}}(33) \mathrm{f}_{\mathrm{n}}(16)$ \\
\hline & 415 & 411 & $f_{\beta}(51) f_{k}(12) f_{g}(19)$ \\
\hline & 489 & 471 & $\mathrm{f}_{\mathrm{n}}(65) \mathrm{f}_{\mathrm{h}}(20) \mathrm{f}_{\mathrm{m}}(17)$ \\
\hline & 555 & 554 & $\mathrm{f}_{\alpha}(61) \mathrm{f}_{\mathrm{m}}(21)$ \\
\hline \multirow[t]{8}{*}{$\mathrm{A}_{2 \mathrm{u}}(\mathrm{IR})$} & $72(103)$ & 81 & $f_{n}(70) f_{\alpha}(24)$ \\
\hline & $128(131)$ & 120 & $\mathrm{f}_{\mathrm{m}}(68) \mathrm{f}_{\mathrm{k}}(24) \mathrm{f}_{\alpha}(12)$ \\
\hline & $150(151)$ & 148 & $\mathrm{f}_{\mathrm{a}}(80) \mathrm{f}_{\mathrm{e}}(14)$ \\
\hline & $190(197)$ & 181 & $\mathrm{f}_{\mathrm{a}}(74) \mathrm{f}_{\mathrm{e}}(20)$ \\
\hline & $365(372)$ & 369 & $\mathrm{f}_{\mathrm{p}}(54) \mathrm{f}_{\mathrm{n}}(30)$ \\
\hline & $420(421)$ & 411 & $\mathrm{f}_{\mathrm{p}}(62) \mathrm{f}_{\beta}(18) \mathrm{f}_{\mathrm{n}}(10)$ \\
\hline & $444(454)$ & 449 & $\mathrm{f}_{\mathrm{p}}(66) \mathrm{f}_{\beta}(20) \mathrm{f}_{\eta}(10)$ \\
\hline & $607(616)$ & 592 & $\mathrm{f}_{\beta}(40) \mathrm{f}_{\beta}(19) \mathrm{f}_{\mathrm{n}}(11)$ \\
\hline \multirow[t]{2}{*}{$\mathrm{B}_{2 \mathrm{u}}$} & 133 & 138 & $\mathrm{f}_{\mathrm{p}}(54) \mathrm{f}_{\mathrm{n}}(26) \mathrm{f}_{\mathrm{e}}(15)$ \\
\hline & 306 & 309 & $\mathrm{f}_{\mathrm{a}}(40) \mathrm{f}_{\mathrm{g}}(35) \mathrm{f}_{\mathrm{n}}(10)$ \\
\hline \multirow[t]{10}{*}{$\mathrm{E}_{\mathrm{u}}$} & $70(70)$ & 69 & $\mathrm{f}_{\beta}(70) \mathrm{f}_{\mathrm{c}}(20)$ \\
\hline & $101(101)$ & 105 & $\mathrm{f}_{\mathrm{a}}(66) \mathrm{f}_{\mathrm{e}}(21)$ \\
\hline & $145(145)$ & 152 & $\mathrm{f}_{\mathrm{a}}(71) \mathrm{f}_{\mathrm{c}}(20)$ \\
\hline & $225(225)$ & 228 & $\mathrm{f}_{\mathrm{a}}(41) \mathrm{f}_{\alpha}(14) \mathrm{f}_{\mathrm{c}}(21)$ \\
\hline & $359(359)$ & 358 & $\mathrm{f}_{\mathrm{c}}(61) \mathrm{f}_{\mathrm{e}}(16) \mathrm{f}_{\mathrm{k}}(14)$ \\
\hline & $387(397)$ & 390 & $\mathrm{f}_{\beta}(64), \mathrm{f}_{\mathrm{c}}$ \\
\hline & $435(446)$ & 441 & $f_{\beta}(56), f_{g}$ \\
\hline & $451(456)$ & 458 & $\mathrm{f}_{\beta}(64) \mathrm{f}_{\mathrm{p}}(28)$ \\
\hline & $555(556)$ & 562 & $\mathrm{f}_{\mathrm{n}}(65) \mathrm{f}_{\alpha}(21)$ \\
\hline & $569(563)$ & 571 & $\mathrm{f}_{\eta}(71) \mathrm{f}_{\alpha}(20)$ \\
\hline
\end{tabular}




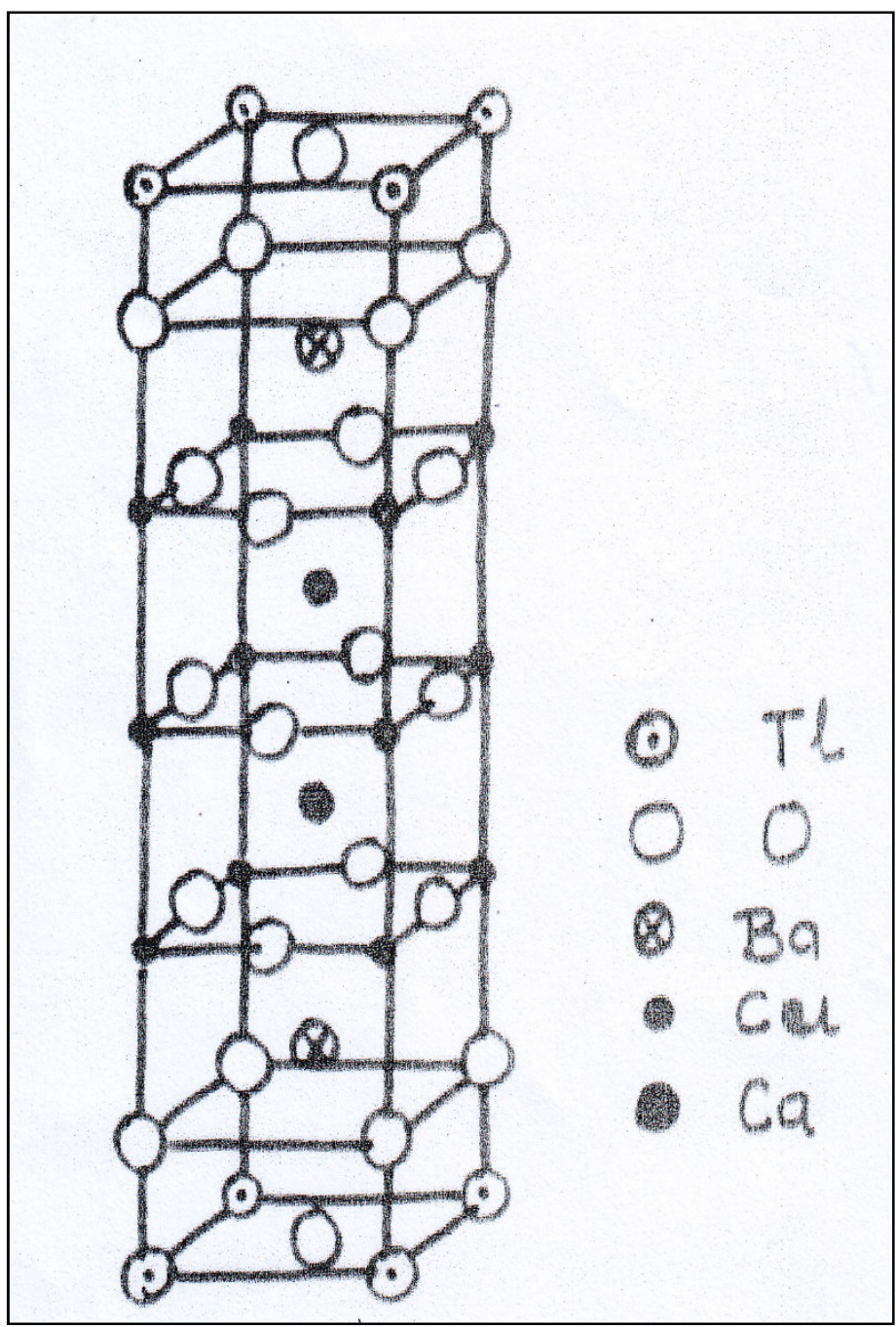

Fig. 1. Unit Cell of $\mathrm{Tl}_{2} \mathrm{Ca}_{2} \mathrm{Ba}_{2} \mathrm{Cu}_{3} \mathrm{O}_{10}$ 